\title{
Lymphangioma circumscriptum of the vulva and Klippel-Trenaunay syndrome
}

\section{Selma El Kadiri, Hanane Baybay, Rhizlane Chaoui, Zakia Douhi, Sara Elloudi, Fatima Zahra Mernissi}

Department of Dermatology and Venereology, University Hospital Hassan II, Fez, Morocco

Corresponding author: Dr. Selma El Kadiri, E-mail: elkadiri-s@hotmail.com

Sir,

Lymphangioma circumscriptum is a rare vascular malformation affecting the lymphatic vessels of the papillary dermis [1]. Klippel-Trenaunay sydrome is a congenital vascular malformation characterized by venous varicosities, soft tissue and/or bony hypertrophy [2]. Here we report a case of association of Lymphangioma circumscriptum of the vulva and Klippel-Trenaunay syndrome.

A 42-year-old female, who has been diagnosed as Klippel-Trenaunay syndrome (KTS), presented with oozy and chronic lesions over the right labium majus that has been present for more than 6 years diagnosed initially as genital warts. The dermatological examination noted the presence of a group of multiple red-purple papules and verrucous vesicles over the right swollen labium majus (Fig. 1). Dermoscopy showed multiple lacunae surrounded by pale septa (Fig. 2). Meanwhile, her right limbs were covered by a large geographic telangectasia (Figs. 3a and 3b). Histopathology of labium majus lesion revealed large, irregular and dilated thin -walled lymphatic channels and endothelial vasculatures in the papillary and reticular dermis without dysplasia or signs of Human Papillomavirus infection. Finally, a diagnosis of LC associated with KTS was confirmed. Our patient was treated by surgical excision with good improvement. Our case is quite particular by demonstrating the interest of dermoscopy in differentiating lymphangioma circumscriptum from genital warts, angiokeratomas and molluscum contagiosum. The presence of lacunae defined as roundish of ovalar clustered, well-demarcated, yellowish, reddish or dark-coloured structures which

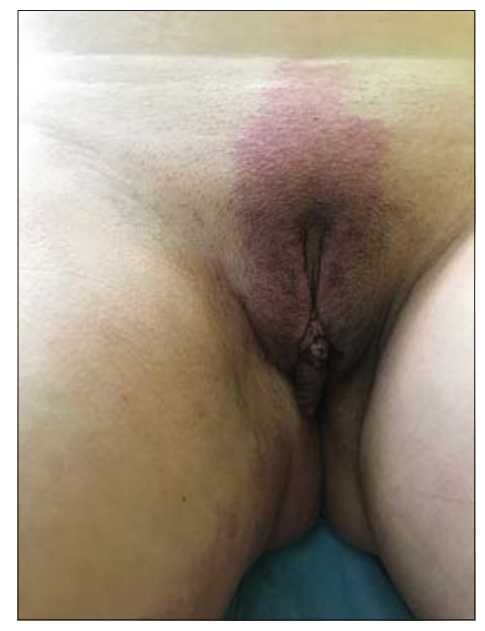

Figure 1: Lesions of lymphangioma circumscriptum.

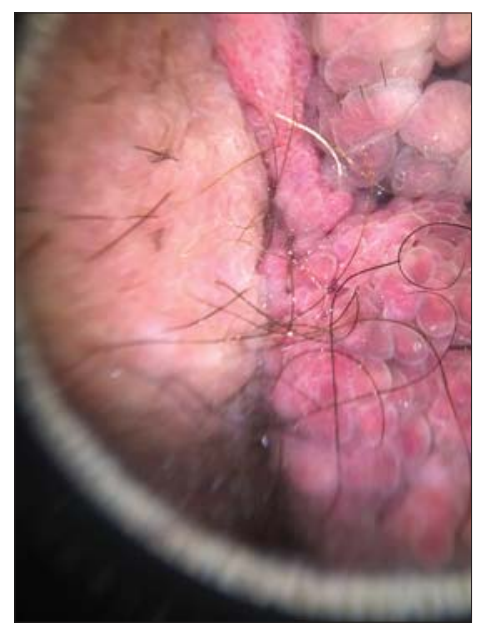

Figure 2: Dermoscopy [non polarized, 10X] revealed multiple lacunae surrounded by pale septa.

orient us to lymphatic malformation [3]. In their study of 45 cases, Zaballos and al demonstrated that lacuane

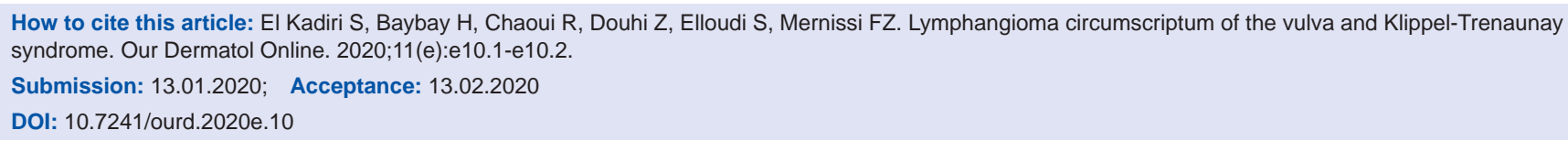




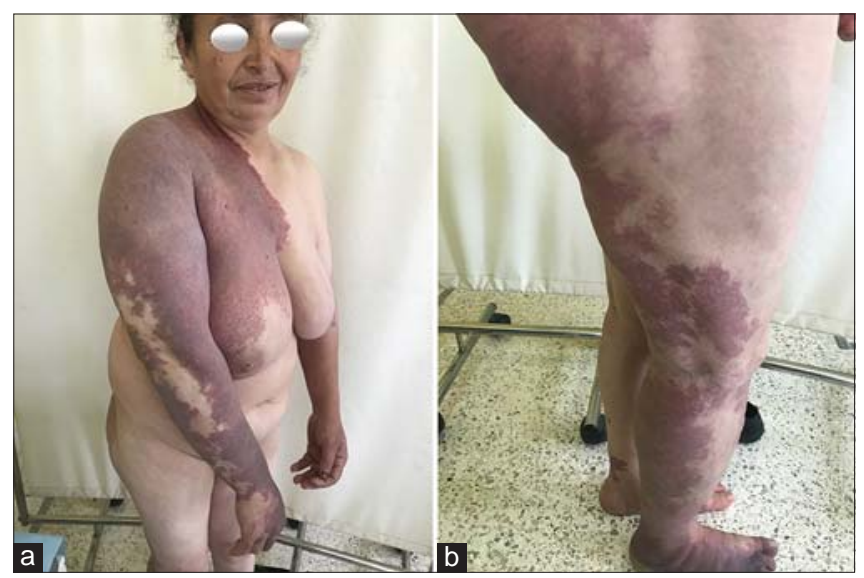

Figure 3: $(a$ and $b)$ Large port-wine stain on most of the right lower et upper limb.

are the most specific dermoscopic features [4]. Genital warts are also characterized by vascular structures but they are red loops or dots surrounded by a white halo [5]. Here we report a case of association of vulvar lymphangioma circumscriptum and Klippel-Trenaunay syndrome oriented by dermoscopy.

\section{Consent}

The examination of the patient was conducted according to the Declaration of Helsinki principles.
The authors certify that they have obtained all appropriate patient consent forms. In the form the patient(s) has/have given his/her/ their consent for his/her/their images and other clinical information to be reported in the journal. The patients understand that their names and initials will not be published and due efforts will be made to conceal their identity, but anonymity cannot be guaranteed.

\section{REFERENCES}

1. Liu XY, Zhang S, Zhang H, Jia J, Cai L, Zhang JZ. Lymphangioma circumscriptum in vulva with Klippel-Trenaunay Syndrome. Chin Med J (Engl). 2018;131:490-1.

2. Yoon G, Kim HS, Lee YY, Kim TJ, Choi CH, Kim BG, et al. Clinical outcomes of primary surgical treatment for acquired vulvar lymphangioma circumscriptum. Arch Gynecol Obstet. 2016;293:157-62.

3. Jha AK, Lallas A, Sonthalia S. Dermoscopy of cutaneous lymphangioma circumscriptum. Dermatol Pract Concept. 2017;7:37-8.

4. Zaballos P. Dermoscopy of lymphangioma circumscriptum: A morphological study of 45 cases. Australas J Dermatol. 2018;59:e189-93.

5. Zalaudek I, Giacomel J, Cabo H, Di Stefani A, Ferrara G, HofmannWellenhof R, et al. Entodermoscopy: a new tool for diagnosing skin infections and infestations. Dermatology. 2008;216:14-23.

Copyright by Selma El Kadiri, et al. This is an open-access article distributed under the terms of the Creative Commons Attribution License, which permits unrestricted use, distribution, and reproduction in any medium, provided the original author and source are credited.

Source of Support: Nil, Conflict of Interest: None declared. 